\title{
THE ASPEN (POPULUS TREMULA L.) FROM THE SOUTHERN CARPATHIANS
}

\author{
Lucian Dincă $^{1, *}$, Emilia Vechiu ${ }^{1}$ \\ 1 “Marin Drăcea" National Institute for Research and Development in Forestry, Braşov, Romania
}

\begin{abstract}
Within the Carpathians, the Southern Carpathians are located in the South part and contains the largest number of peaks situated at over 2500 meters altitude. Aspen (Populus tremula L.) is a pioneer species with a rapid growth, usually found in the temperate and boreal areas from Eurasia. In our country, the species is present in hill and mountain areas, up to $1600 \mathrm{~m}$ in altitude and in mixture forests.

The purpose of this article is to analyze aspen strands from the Southern Carpathians from the point of view of site and growth conditions. In order to achieve this, we have used data from forest management plans realized during 1982 2006 for 35 forest districts located in this area. The stand and site characteristics that were analyzed were the following: location, pruning, current growth, production class, structure, slope, exposition, altitude and forest type. The surface occupied by aspen stands in the Southern Carpathians is of 2302 ha, with the majority located in the southeast part. Aspen stands from this area are characterized by a mixt or intimate mixture, low pruning, current growth of 0.4$0.8 \mathrm{~m}^{3} /$ year/ha, medium and inferior production classes, and an even-aged, relatively even-aged and relatively unevenaged structure. They vegetate on fields with a high or very high slope, at average altitudes between 700 and $1100 \mathrm{~m}$, in mountain common beech stands or fir, Norway spruce and common beech mixtures.
\end{abstract}

Keywords: altitude, aspen, exposition, site conditions, slope

\section{INTRODUCTION}

The Carpathians are a mountain chain that covers approximately $1.500 \mathrm{~km}$, with half of this surface being present in Romania. These mountains host the most representative forest ecosystem from Europe, numerous endemic plants and animals as well as natural parks and reservations. The main tree species that dominate the Carpathian forests are: common beech (Fagus sylvatica L.), Norway spruce (Picea abies L.), fir (Abies alba Mill.) and Pinus species (Bytnerowicz et al., 2002; Vădineanu et al., 2008, Magyari et al., 2012). Some of these stands are very old (Cântar et al., 2019) or are smart forests (Dincă et al., 2019). The Southern Carpathians are located in South Romania and are the highest mountains, having 11 peaks that exceed $2500 \mathrm{~m}$ in altitude. The tallest peak (Moldoveanu Peak) is located in Făgăraş Mountains, having an altitude of $2544 \mathrm{~m}$. These mountains are formed on crystalline schist rocks (predominant) and on sedimentary ones at the basis (Kuhlemann et al., 2013; Magori et al., 2017). The climate is levelled, based on altitudes so that the climate is temperate in lower areas and alpine as the altitude increases (Tóth et al., 2015; Necsoiu et al., 2016; Vincze et al., 2017) 


\section{Current Trends in Natural Sciences}

Vol. 9, Issue 17, pp. 168-174, 2020

https://doi.org/10.47068/ctns.2020.v9i17.020

Current Trends in Natural Sciences (on-line)

ISSN: 2284-953X

Current Trends in Natural Sciences (CD-Rom)

ISSN: 2284-9521

ISSN-L: 2284-9521

ISSN-L: 2284-9521

Aspen (Populus tremula L.) is a pioneer species with a rapid growth and present in temperate and boreal regions from Eurasia (figure 1).

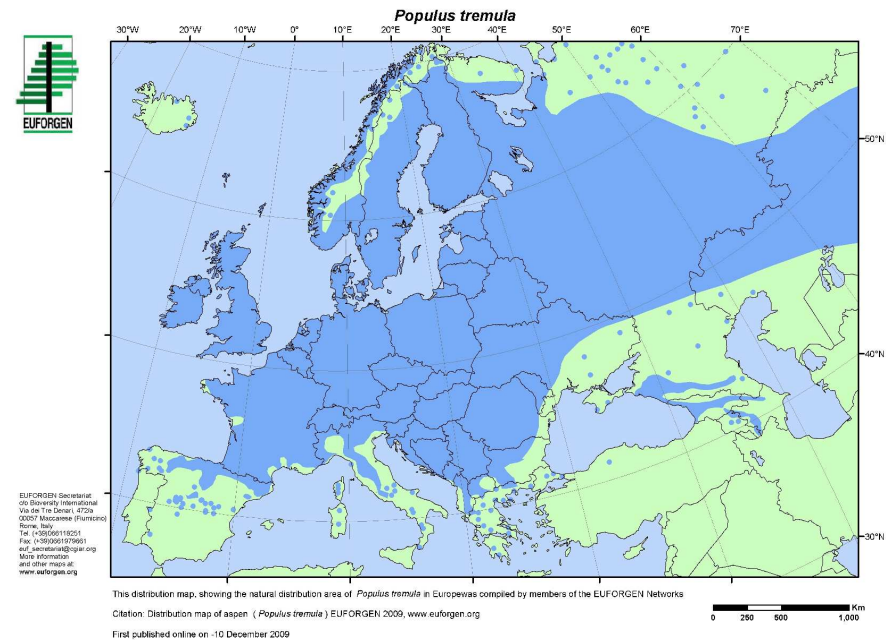

Figure 1. Distribution areal of aspen (http://www.euforgen.org/species/populus-tremula/)

The species is present in our country both in the hill area (rarely in the plain one) as well as in the mountain area, up to $1600 \mathrm{~m}$ altitudes and in mixture with other species. The aspen can regenerate both vegetatively, by active suckers or through seeds, settling rapidly on fields that lack vegetation. The sucker capacity varies based on the age and site conditions. The species has a high ecologic adaptability, supports well the heath but not drought and it vegetates well on slope fields, on salty soils as well as on soils rich in nutritive substances as well as on poor, oligo basic or acid ones (Suvanto and Latva-Karjanmaa 2005; Şofletea and Curtu 2007; Myking et al., 2011; Caudullo and de Rigo, 2016). Aspen has similar ecological requests with the alder (Blaga et al., 2019), having an important role in the greening of humid fields (Kachova and Dincă, 2015; Constandache et al., 2018; Constandache et al., 2019) or against landslides (Dincă and Achim, 2019).

As such, the purpose of this paper is to analyse aspen stands located in the Southern Carpathians from the point of view of their site and growth conditions.

\section{MATERIALS AND METHODS}

The material that was used for this article is represented by data from forest management plans for all forest districts located in the Southern Carpathians (35 forest districts) realized during 19822006 (older forest management plans were considered as they correspond to a larger forest surface present before retrocession). The total elements of aspen stands are represented by 1244 lines with 53 columns (that represent certain stand or site characteristics). Amongst them, the analysed aspects are referring to: location, mixture, pruning, current growth, production class, structure, slope, exposition, altitude and forest type.

\section{RESULTS AND DISCUSSIONS}

The spread of aspen stands in the Southern Carpathians: aspen stands are present in all forest districts from this area, with preponderance in Cornet, Polovragi, Brezoi, Valea Cibinului, Muşăteşti, Bumbeşti, Novaci, Făgăraş, and Arpaş Forest Districts (figure 2). They cover a total surface of 2302 ha, almost a double surface than ash stands from the same area (Dincă et al., 2019). 


\begin{tabular}{lrr}
\hline & $\begin{array}{c}\text { Current Trends in Natural Sciences } \\
\text { Vol. 9, Issue 17, pp. 168-174, 2020 } \\
\end{array}$ & Current Trends in Natural Sciences (CD-Rom) \\
& ISSN: 2284-9521 \\
Current Trends in Natural Sciences (on-line) & ISSN-L: 2284-9521 \\
ISSN: 2284-953X & & ISSN-L: 2284-9521 \\
ISS/10.47068/ctns.2020.v9i17.020
\end{tabular}

An increased presence of aspen on the southeast side of the Southern Carpathians can also be observed.

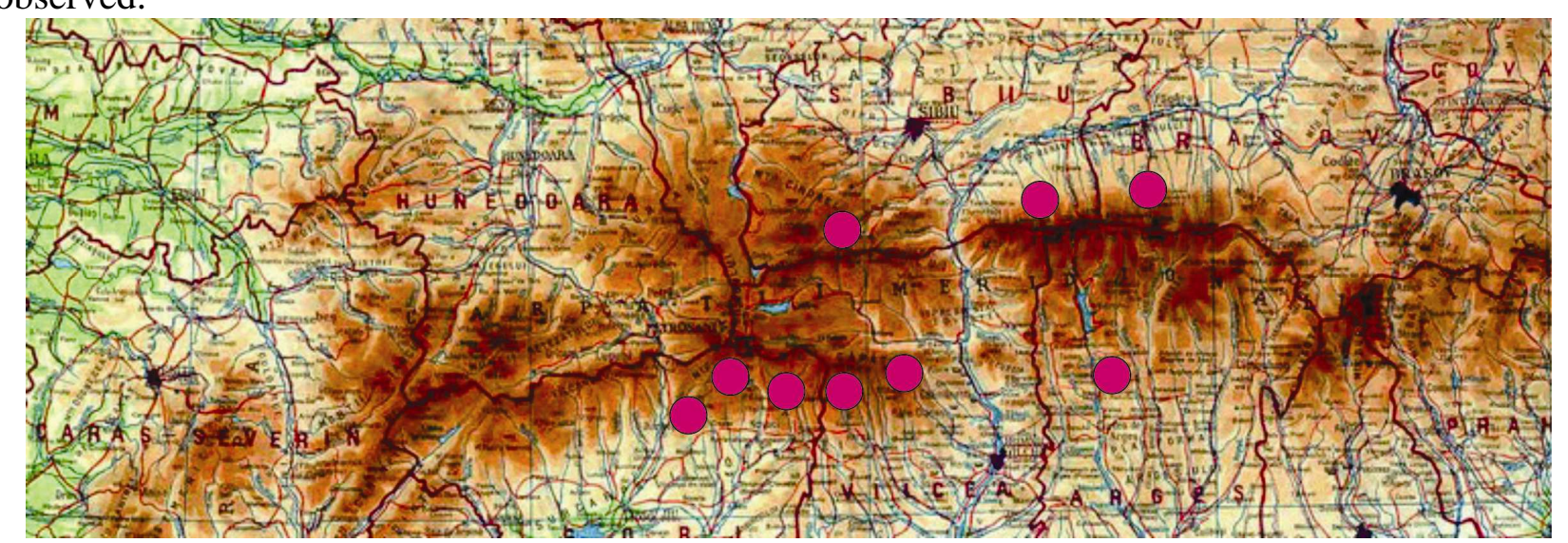

Figure 2. Distribution of aspen stands in the Southern Carpathians

\section{The characteristics of aspen stands from the Southern Carpathians:}

The aspen stands have a mixed composition, consisting of the following types of mixture: intimate (1085 ha), in bouquets (1108 ha) and in groups (109 ha).

In Norway aspen is found in intimate mixtures in mixtures with Norway spruce and rather with Scots pine in Scandinavia (Worrell, 1995).

Pruning is the process by which the twigs at the base are removing naturally, thus improving wood quality (Rytter and Jansson, 2009). The majority of aspen trees have a pruning between 0.4 and 0.6 with the exception of very young trees that record lower values (figure 3 ).

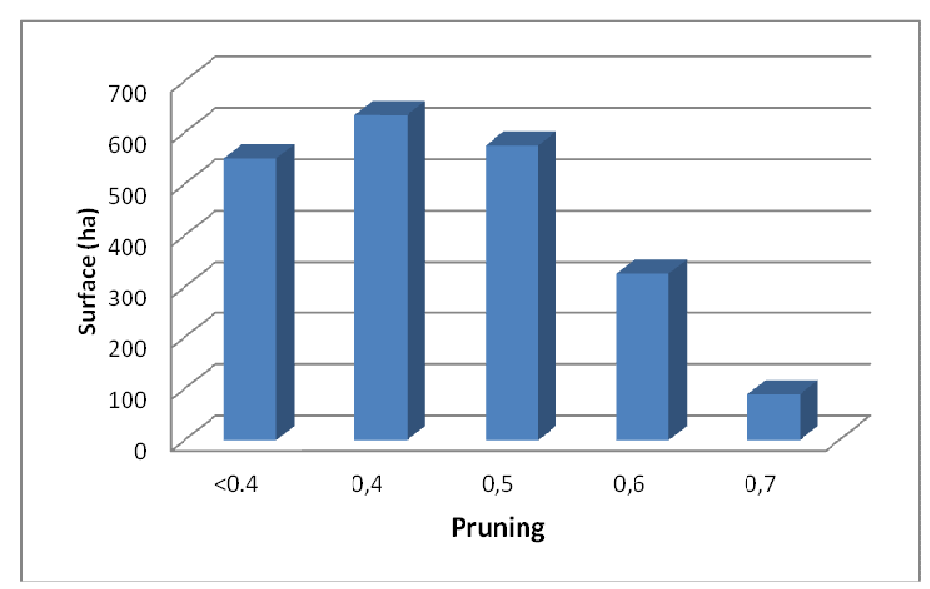

Figure 3. Pruning of aspen trees from the Southern Carpathians

The current growth of aspen strands from this area ranges between $0.1 \mathrm{~m}^{3} / \mathrm{year} / \mathrm{ha}$ and 4.8 $\mathrm{m}^{3} /$ year/ha, with the majority of stands recording growths of $0.4-0.8 \mathrm{~m}^{3} /$ year/ha (figure 4 ). Even though it is a pioneer species, aspen does not record significant growths. This aspect is correlated with the fact that the species does not have advanced ages, being usually replaced by main species in the stand's composition. 


\section{Current Trends in Natural Sciences}

Vol. 9, Issue 17, pp. 168-174, 2020

https://doi.org/10.47068/ctns.2020.v9i17.020

Current Trends in Natural Sciences (on-line)

\section{Figure 4. Current growth of aspen stands from the Southern Carpathians}

The production class is influenced by the edapho-climatic conditions and represents production capacity of the tree. This category is mainly represented by average (class $3=888 \mathrm{ha}$ ) and inferior production classes (class $4=897$ ha and class $5=302$ ha), while superior production stands occupy only small surfaces (class $1=16$ ha and class $2=200$ ha) (figure 5 ).

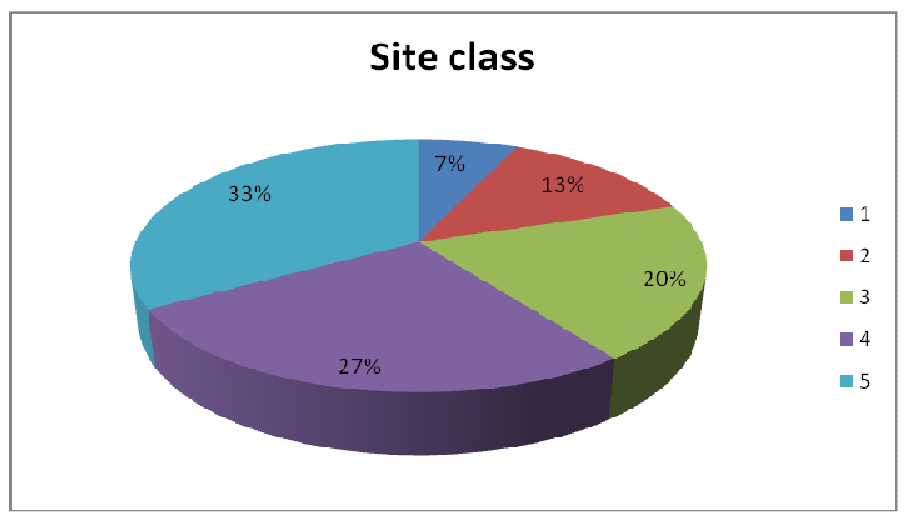

Figure 5. Production class of aspen stands from the Southern Carpathians

The horizontal and vertical distribution of the trees shows the stands structure (Duduman, 2011). In which aspen is integrated is relatively equal between even-aged stands (930 ha), relatively evenaged stands (546 ha) and relatively uneven-aged stands (827 ha) (figure 6).

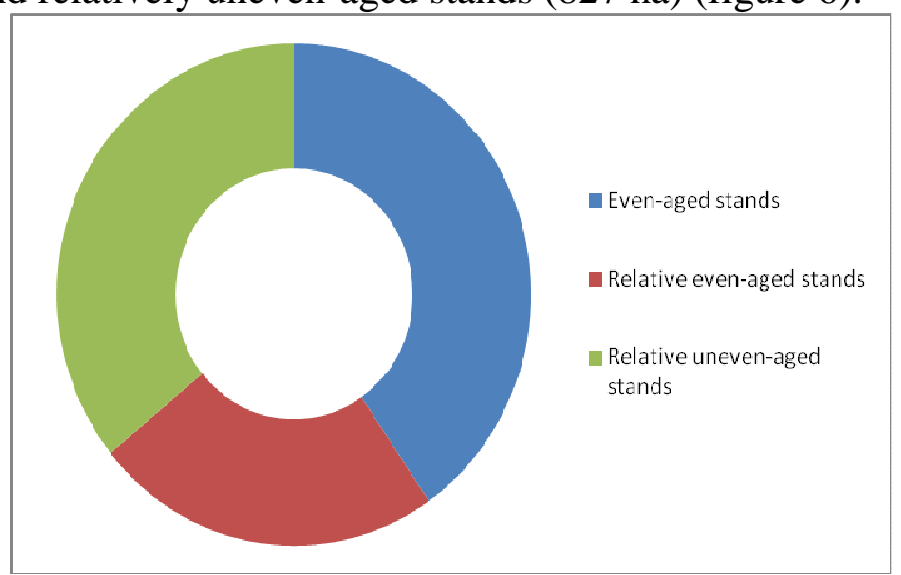

Figure 6. The structure of aspen stands from the Southern Carpathians 


\section{Current Trends in Natural Sciences}

Vol. 9, Issue 17, pp. 168-174, 2020

https://doi.org/10.47068/ctns.2020.v9i17.020

Current Trends in Natural Sciences (on-line)

ISSN: 2284-953X

Current Trends in Natural Sciences (CD-Rom)

ISSN: 2284-9521

ISSN-L: 2284-9521

ISSN-L: 2284-9521

\section{Field slope}

The aspen is spread out on fields with slopes that range from low $0-20^{\circ}$ (394 ha), average $21-30^{\circ}$ (458 ha), especially high $31-40^{\circ}$ (886 ha) and very high $>40^{\circ}$ (565 ha) (figure 7 ).

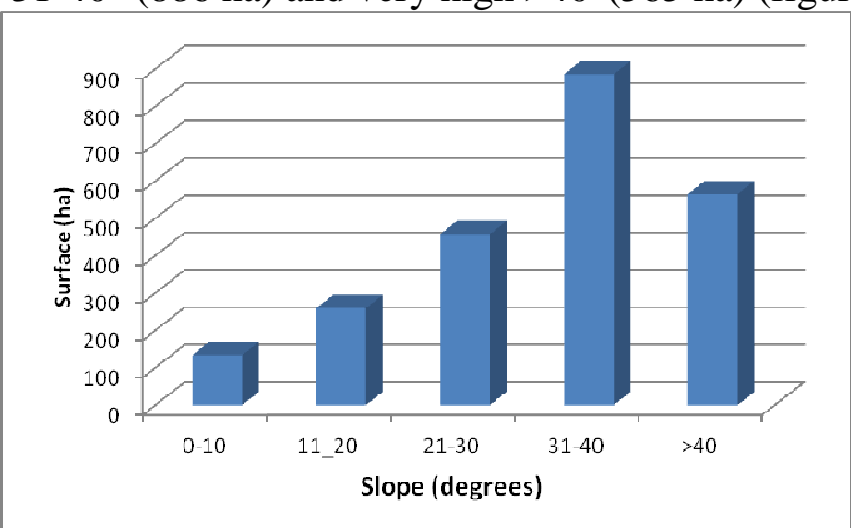

Figure 7. Slopes of aspen stands from the Southern Carpathians

In the case of slope fields with aspen species, the main expositions are SouthEast (445 ha) and NorthEast (368 ha), while the least common are the West (184 ha), North (198 ha) and East ones (199 ha) (figure 8).

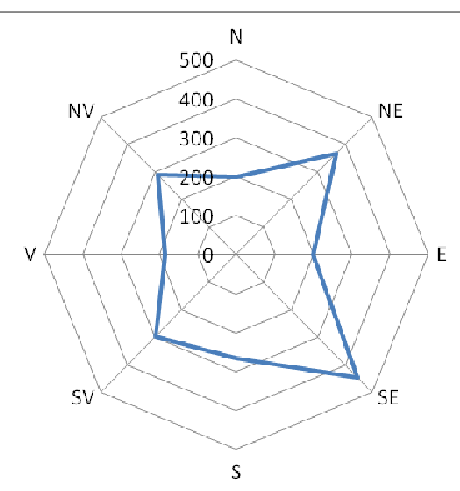

Figure 8. The exposition of aspen stands from the Southern Carpathians

The altitude at which aspen appears in the Southern Carpathians ranges between $270 \mathrm{~m}$ at Polovragi and $1550 \mathrm{~m}$ at Cornet. The most common altitudes are gathered between 700 and $1100 \mathrm{~m}$ (figure 9).

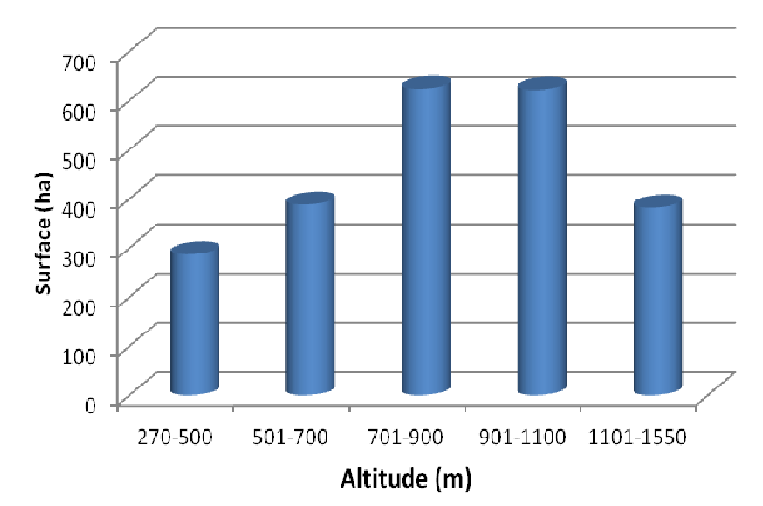

Figure 9. The altitude of aspen stands from the Southern Carpathians 
The forest types characteristic for the aspen located in this area are: Mountain common beech stand on skeleton soils with mull flora (476 ha), Mountain common beech with Luzula luzuloides (228 ha), Hill common beech on skeleton soils with mull flora (157 ha), and Mixture of fir, Norway spruce and common beech on crystalline cliffs (119 ha).

\section{CONCLUSIONS}

The characterization of the geomorphology of the studied area was made with the data from forest management plans (mixture, pruning, current growth, production class, structure, slope, exposition, altitude and forest type) for all forest districts located in the Southern Carpathians.

Aspen is one of the species that rapidly installs itself on fields lacking in forest vegetation, having a high ecologic adaptability. Geomorphological conditions such as altitude, terrain slope and exposure do not decisively influence the appearance of these stands.

From the point of view of site conditions, these forests are mainly distributed on South-East and North-East expositions, on fields with high slopes, at altitudes between 700-1100 m, and in common beech forests or mixtures of resinous and broadleaved species.

The majority of stands are situated in average (class $3=888 \mathrm{ha}$ ) and inferior production classes (class $4=897$ ha and class 5=302 ha). They record an average current growth of $0.4-0.8 \mathrm{~m}^{3} / \mathrm{an} / \mathrm{ha}$ as they don't reach old ages, being replaced by the stand's composition main species.

\section{REFERENCES}

Blaga, T., Dinca, L., Pleşca, I.M. (2019). How can smart alder forests (Alnus glutinosa (L.) Gaertn.) from the Southern Carpathians be indentified and managed. Scientific papers series „Management, Economic Engineering in Agriculture and Rural Development”, 19 (4), 29-35.

Bytnerowicz, A., Godzik, B., Frącze, W., Grodzińsk, K., Krywult, M., Badea, O., Mankovska, B. (2002). Distribution of ozone and other air pollutants in forests of the Carpathian Mountains in central Europe. Environmental Pollution, 116(1), 3-25.

Caudullo, G., de Rigo, D. (2016). Populus tremula in Europe: distribution, habitat, usage and threats. European Atlas of Forest Tree Species. Publ. Off. EU, Luxembourg, 138-139.

Cântar, I.C., Dincă, L., Chisăliță, I., Crişan, V., Kachova, V. (2019). Identifying the oldest stands from the Southern Carpathians together with their main characteristics. Proceedings of the Multidisciplinary Conference on Sustainable development, Filodiritto International Proceedings, 186-193.

Constandache, C., Dincă, L., Tudose, N.C., Panaitescu, C. (2018). Protecting surface water resources through silvicultural methods. International Symposium "The Environment and the Industry", Simi 2018, Proceedings book Section Pollution Assessment \& Management Systems, 276-284.

Constandache, C., Dincă, L., Popovici, L., Tudor, C. (2019). The role of forest vegetation in the mitigation of the ecological imbalances resulting from climate change in Putna-Vrancea river basin. International Symposium "The Environment and the Industry" SIMI 2019, Proceeding book, 98-106.

Dincă, L., Constandache, C. (2019). European ash (Fraxinus excelsior L.) stands from the Southern Carpathians. ISBINMA TEH Agricultural and Mechanical Engineering, Book of International Symposium, 128-133.

Dincă, L., Murariu, G., Iticescu, C., Budeanu, M., Murariu A. (2019). Norway spruce (Picea abies (L.) Karst.) smart forests from Southern Carpathians. International Journal of Conservation Science, 10(4), 781-790.

Dincă, L., Achim, F., (2019). The management of forests situated on fields susceptible to landslides and erosion from the Southern Carpathians. Scientific papers series Management, Economic Engineering in Agriculture and Rural Development, 19(3), 183-188.

Duduman, G. (2011). A forest management planning tool to create highly diverse uneven-aged stands. Forestry, 84(3), 301-314.

Kachova, V., Dincă, L. (2015). Establishment of agro-forestry systems along river basins-Functions and features. Revista de Silvicultură şi Cinegetică, 20(36), 64-68.

Kuhlemann, J., Dobre, F., Urdea, P., Krumrei, I., Gachev, E., Kubik, P., Rahn, M. (2013). Last glacial maximum glaciation of the Central South Carpathian range (Romania). Austrian Journal of Earth Sciences, 10(2), 50-68. 
Magori, B., Onaca, A., Urdea, P. (2017). The influence of contributing area parameters on the size of rock glaciers in the Southern Carpathian Mountains. In Forum Geografic, 16(1). 5-11.

Magyari, E.K., Jakab, G., Bálint, M., Kern, Z., Buczkó, K., Braun, M. (2012). Rapid vegetation response to Lateglacial and early Holocene climatic fluctuation in the South Carpathian Mountains (Romania). Quaternary Science Reviews, 35, 116-130.

Myking, T., Bøhler, F., Austrheim, G., Solberg, E. J. (2011). Life history strategies of aspen (Populus tremula L.) and browsing effects: a literature review. Forestry, 84(1), 61-71.

Necsoiu, M., Mîndrescu, M., Onaca, A., Wigginton, S. (2016). Recent morphodynamics of alpine lakes in Southern Carpathian Mountains using high-resolution optical imagery. Quaternary International, 415, 164-174.

Rytter, L., Jansson, G. (2009). Influence of pruning on wood characters in hybrid aspen. Silva Fennica, 43(4), 689-698.

Suvanto, L.I., Latva-Karjanmaa, T.B. (2005). Clone identification and clonal structure of the European aspen (Populus tremula). Molecular Ecology, 14(9), 2851-2860.

Şofletea, N., Curtu, L. (2007). Dendrologie [Dendrology], Braşov, Transilvania University of Braşov.

Tóth, M., Magyari, E.K., Buczkó, K., Braun, M., Panagiotopoulos, K., Heiri, O. (2015). Chironomid-inferred Holocene temperature changes in the South Carpathians (Romania). The Holocene, 25(4), 569-582.

Vădineanu, A., Badea, O., Gheorghe, I.F., Neagu, Ş., Postelnicu, D. (2008). New insights on the dynamics of the forest vegetation from the Romanian Carpathian Mountains. Ekológia (Bratislava), 27(3), 269-286.

Vincze, I., Orbán, I., Birks, H.H., Pál, I., Finsinger, W., Hubay, K., ... Tóth, M. (2017). Holocene treeline and timberline changes in the South Carpathians (Romania): Climatic and anthropogenic drivers on the southern slopes of the Retezat Mountains. The Holocene, 27(11), 1613-1630.

Worrell, R. (1995). European aspen (Populus tremula L.): a review with particular reference to Scotland II. Values, silviculture and utilization. Forestry: An International Journal of Forest Research, 68(3), 231-244.

Anonymous (1988-2012). Amenajamentele ocoalelor silvice [Management plans]: Aninoasa (2005), Arpaş (1986), Avrig (2005), Baru (1996), Braşov (1993), Brezoi (1991), Bumbeşti (2002), Câmpulung (2006), Cornet (1993), Cugir (1993) Domneşti (2004), Făgăraş (1985), Grădişte (2004), Latorița (1994), Lupeni (2000), Muşăteşti (1994), Novaci (2002), Orăştie (1993), Petroşani (2001), Pietroşița (2005), Polovragi (2001), Râşnov (1993), Retezat (1996), Rucăr (1996), Runcu (2000), Şercaia (1986), Şuici (2008), Tălmaciu (1980), Teliu (1993), Valea Cibinului (1982), Valea Sadului (1982), Vidraru (2005), Voila (1985), Voineasa (2003), Zărneşti (1993).

http://www.euforgen.org/species/populus-tremula/ 